\title{
Using narratives to understand the motivational factors and experience of being a self-initiated academic expatriate in South Africa
}

\begin{tabular}{|c|c|}
\hline \multicolumn{2}{|c|}{$\begin{array}{l}\text { Authors: } \\
\text { Tinashe T. Harry }{ }^{1} \\
\text { Nicole M. Dodd }^{2} \\
\text { Willie T. Chinyamurindi }^{1} \text { (D) }\end{array}$} \\
\hline \multicolumn{2}{|c|}{$\begin{array}{l}\text { Affiliations: } \\
\text { }{ }^{1} \text { Department of Industrial } \\
\text { Psychology, University of Fort } \\
\text { Hare, South Africa }\end{array}$} \\
\hline \multicolumn{2}{|c|}{$\begin{array}{l}{ }^{2} \text { Department of Industrial } \\
\text { Psychology (Military), } \\
\text { Stellenbosch University, } \\
\text { South Africa }\end{array}$} \\
\hline \multicolumn{2}{|c|}{$\begin{array}{l}\text { Corresponding author: } \\
\text { Willie Chinyamurindi, } \\
\text { chinyaz@gmail.com }\end{array}$} \\
\hline \multicolumn{2}{|c|}{$\begin{array}{l}\text { Dates: } \\
\text { Received: } 07 \text { Feb. } 2016 \\
\text { Accepted: } 05 \text { July } 2017 \\
\text { Published: } 31 \text { Aug. } 2017\end{array}$} \\
\hline \multicolumn{2}{|c|}{$\begin{array}{l}\text { How to cite this article: } \\
\text { Harry, T.T., Dodd, N.M., \& } \\
\text { Chinyamurindi, W.T. (2017). } \\
\text { Using narratives to } \\
\text { understand the motivational } \\
\text { factors and experience of } \\
\text { being a self-initiated } \\
\text { academic expatriate in South } \\
\text { Africa. SA Journal of Human } \\
\text { Resource Management/ } \\
\text { SA Tydskrif vir } \\
\text { Menslikehulpbronbestuur, } \\
\text { 15(0), a797. https://doi. } \\
\text { org/10.4102/sajhrm. } \\
\text { v15i0.797 }\end{array}$} \\
\hline \multicolumn{2}{|c|}{$\begin{array}{l}\text { Copyright: } \\
\text { (c) 2017. The Authors. } \\
\text { Licensee: AOSIS. This work } \\
\text { is licensed under the } \\
\text { Creative Commons } \\
\text { Attribution License. }\end{array}$} \\
\hline \multirow[b]{2}{*}{ 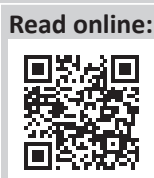 } & \\
\hline & $\begin{array}{l}\text { Scan this QR } \\
\text { code with your } \\
\text { smart phone or } \\
\text { mobile device } \\
\text { to read online. }\end{array}$ \\
\hline
\end{tabular}

Orientation: A growing movement of foreign nationals is settling in South Africa. Given this, there is a need to understand not only those factors influencing foreign nationals to settle in South Africa but also their lived experiences as a basis for individual career development.

Research purpose: To investigate the expatriation motivational factors and experiences of selfinitiated academic expatriates in South Africa.

Motivation for the study: Calls have been made within the careers literature for more empirical focus on understanding career development using some of the neglected sample groups.

Research approach, design and method: The interpretive paradigm was adopted to understand the main purpose of the study. Guided by study objectives, unstructured interviews were conducted using a sample of foreign academics working in South Africa $(n=25)$.

Main findings: Individual stories and narratives highlighted that academics relocated for the following reasons: (1) individual preference, (2) economic meltdown and (3) political conditions. Furthermore, the lived experiences of the expatriates reflected discrimination within the workplace and the community of residences in South Africa.

Practical and managerial implications: Research findings indicate that the human resources (HR) function can come up with interventions that positively influence the lived experience and career development of foreign academics working in South Africa.

Contribution: The expatriate experience framed in this study provides a picture of the career development processes of neglected sample groups in the extant literature. Such an understanding is key in advancing literature and proposing interventions. All this is important given the global trend on labour and skills movement added to the role South Africa plays in the international arena.

\section{Introduction}

Many individuals are now looking beyond their home countries in search of career opportunities and a better life. Mostert (2014) attributes the movement of labour to globalisation. This has allowed host countries the opportunity to not only attract but also retain skilled professionals within their workplace (Silvanto \& Ryan, 2014). Ryan, Silvanto and Ozkaya (2015) observe that host countries have had to lower their migration requirements so as to attract skilled foreign nationals. Fundamentally, this has changed not only the nature of work but also the view of the notion of a career (Baruch, Dickmann, Altman \& Bournois, 2013; Rodriguez \& Scurry, 2014).

Such international trends have led to the rise of, and need to investigate, self-initiated expatriates (SiEs) as an important source of talent (Doherty, 2013; Haslberger \& Vaiman, 2013). The major difference between $\mathrm{SiEs}$ and traditional expatriates is the initiative to move (Andresen, Al Ariss \& Walther, 2012; Selmer \& Lauring, 2012; Suutari \& Brewster, 2000). Accordingly, SiEs are viewed as those individuals choosing to pursue international careers on their own initiative (Cao, Hirschi \& Deller, 2013; Tharenou \& Caulfied, 2010) and who finance their own expatriation for personal and career development. For $\mathrm{SiE}$, the initiative to expatriate is therefore a personal choice, not an organisation's (Richardson \& Mallon, 2005). Despite the rise in SiE, little empirical focus exists internationally (Doherty, 2013). This even extends to the South African setting as well.

Furthermore, calls have been made for understanding the concept of boundaryless or protean careers (Abele, Spurk \& Vomer, 2012; Al Ariss, Cascio \& Paauwe, 2013; Carr, Inkson \& Thorn, 2005; 
Hall, 2002; Inkson, Gunz, Ganesh \& Roper, 2012; Tams \& Arthur, 2010). Such career paths are characterised by mobility across different locations. The notion of the SiE can be thought to fit within this categorisation and hence its importance and the need for more research (Richardson, 2009; Selmer \& Lauring, 2011a). Such investigations are warranted for given intensification in the movement of individuals across borders (International Labour Organisation, 2010).

Emerging literature appears to suggest that the decision to expatriate no longer lies with the organisation but rather with the individual (Selmer \& Lauring, 2011a). Calls have been made for research that expands this view (Froese, 2012; Howe-Walsh \& Schyns, 2010). A need thus exists to investigate the $\mathrm{SiE}$ experience as part of a project of the individual (Volpe \& Murphy, 2011), especially amongst academics as their professional skills are easily transferable across countries (Beaverstock, 2005; Richardson \& McKenna, 2003). Furthermore, calls exist for more empirical work to investigate $\mathrm{SiE}$ within the academic context and extend theorising given the mobility within this type of work (Richardson, 2009).

\section{Research purpose and objective}

The purpose of this study was to explore the expatriation motivational factors and the lived experiences of $\mathrm{SiE}$ academics working at a South African rural university. The backdrop of this is twofold. Firstly, theoretically, there is an acknowledgement of the important role SiEs play not just for the home but also the host country (Ainuddin \& Lily, 2012; Doherty, Richardson \& Thorn, 2013; Jokinen, Brewster \& Suutari, 2008). This has even culminated in an argument that such investigations on $\mathrm{SiE}$ can provide a better understanding to the field of work studies (Inkson \& Richardson, 2010). Second is a contextual argument. Although expatriates may face discrimination in academia globally, discrimination against expatriates is worth careful and particular attention in South Africa. This is because South Africa has experienced a spate of violent xenophobic attacks since 1994 (Saleh, 2015). More so, discrimination, specifically xenophobia, is prevalent in South African universities, with expatriate students and staff being exposed to a wide array of xenophobic experiences in South Africa (Buthelezi, 2009; Sorensen, 2012; Singh, 2013). South Africa is simultaneously experiencing a skills crisis, specifically in higher education (Sebola, 2015), and will fail to address its skills shortages over the short term if it cannot attract and retain SiEs. It is therefore necessary to identify and address factors such as discrimination which may deter skilled SiEs from choosing to work in higher education in South Africa. The overall research question guiding this study was: What factors (given the South African context) influence SiEs to expatriate and the ensuing lived experience accompanying this decision?

\section{Factors influencing self-initiated expatriate's movement}

Contemporary career theories emerge, especially because of environmental complexities surrounding modern day careers. This study focused on the boundaryless career theory because of its applicability to knowledge-intensive workers (Inkson et al., 2012). For the purpose of this research study, the boundaryless career theory is divided into physical and psychological mobility. Physical mobility represents the transitions of the participants across boundaries, and psychological mobility illustrates transitions of the individual's perception (Andresen et al., 2012; Chen, 2012). Given this, the thinking could be that the interaction between the physical and psychological plays a part in decisions such as moving from one country to another.

A number of studies have been conducted on the movement of $\mathrm{SiE}$ especially internationally. Within the British context, the need for adventure or travel has been found to be a factor that influences movement of skills (Richardson \& Mallon, 2005; Richardson \& McKenna, 2002). In another study, the need for financial gain and the quest for career development opportunities have been found to influence the movement of younger academics to leave their home countries (Selmer \& Lauring, 2010). In general, studies conducted mostly in western countries attribute a sense of adventure, monetary issues, family and partner considerations, life change and personal development as influencing factors amongst expatriates (Al Ariss \& Syed, 2011; Howe-Walsh \& Schyns, 2010; Selmer \& Lauring, 2011b).

Amongst academics there is acknowledgement that within such professions, skills are easily transferable across countries (Beaverstock, 2005; Richardson \& McKenna, 2003). This is suggested to be a notable pattern in western countries (Maharaj, 2011). Altbach (2004) makes a categorisation of push and pull factors as influencing academics to expatriate. Push factors include motivation such as opportunities for scholarships, better working conditions and better salary. Conversely, pull factors (depending on the individual) may include the need for job security, stability, resource scarcity and the need for better working conditions.

Despite the growing theorising, there are arguments for the need of more empirical focus into the lived experience of SiE (Alshammari, 2013). Further, the role of environmental and social phenomena on this experience is argued to be important in enhancing the expatriate experience (e.g. Richardson, 2006, 2009; Richardson \& Mallon, 2005; Richardson \& McKenna, 2002; Richardson \& Zikic, 2007; Selmer \& Lauring, 2010).

\section{Research design}

\section{Research approach}

A qualitative exploratory research approach was adopted to understand not only the factors but also the lived experiences of SiEs working as academics. This approach helped gain a deeper understanding of the participants' lived experiences (Creswell, 2009) from the subjective view of the individual (Riessman, 2008). Such an approach 
allows for the collection of situational information and extrapolating information that accompanies human actions and decisions (Guba \& Lincoln, 1994).

\section{Research strategy}

Unstructured interviews were deemed as an appropriate method for collecting data, thereby allowing participants to share their experiences freely. The aim here was to generate meaning through participant stories; such stories are viewed by Merriam (2002, p. 286) as tools that allow for 'meaning-making' to understand the 'human experience'. By using unstructured interviews, participants were able to draw meaning from their lived experience and reflect on their experiences and to clarify their responses (Rubin \& Rubin, 2005). This type of interviewing allowed the researcher to elicit stories from the participants rather than brief answers or discrete responses that can be predetermined (Riessman, 2008).

\section{Research method}

\section{Sampling and participants}

A total of 25 participants were selected to take part in this study. The sample for this study was gathered using a combination of sampling methods, namely: judgemental and convenience sampling (Creswell, 2009). In this regard, participants had to be full-time foreign academics who were accessible to the researchers because of time and budget constraints. The demographic characteristics of participants and their pseudonyms (used to protect their identity) are illustrated in Table 1.

\section{Data collection methods}

During the interview process, the researchers recorded notes, and all interviews were recorded and transcribed word for word. Prior to every interview, participants were given a thorough briefing and informed of the expectations, rights and responsibilities around the research. All interviews were conducted in the offices of the academics at the university campus, and inclusion and exclusion criteria protocols were followed. Participants had to be foreign nationals working as full-time academics at a selected university who had initiated their own expatriation.

\section{Recording of the data}

\section{Data analysis}

The interviews were transferred to QSR NVivo 9, which is a data analysis and management software (Reuben \& Bobat, 2014). A data analysis procedure based on three levels of meaning-making, as adopted in previous research, was used (Chinyamurindi, 2012, 2016; McCormack, 2000). Level 1 was helpful in developing a good understanding of the career development experience of each story. This was performed by re-reading each interview and listening to audio recordings. Such a process allowed for the identification of 'markers' of the stories (McCormack, 2000, p. 221) and answering the questions about each interview: 'what kind of story is this?' (Thornhill, Clare \& May, 2004, p. 188). Level 2 was achieved through classifying responses from participants into meaningful categories (Nachmias \& Nachmias, 1996). Finally, in Level 3, the researcher analysed the content of the gathered narrative accounts and themes (McCormack, 2000). This was carried out by identifying

TABLE 1: Participant profiles.

\begin{tabular}{|c|c|c|c|c|c|}
\hline Pseudonym & Gender & Marital status & Nationality & Employment position & Years in South Africa \\
\hline Collin & Male & Married & Zimbabwean & Senior lecturer & 9 \\
\hline Steve & Male & Single & Zimbabwean & Junior lecturer & 6 \\
\hline $\mathrm{Jim}$ & Male & Married & Eritrean & Junior lecturer & 13 \\
\hline Uche & Male & Married & Nigerian & Professor & 11 \\
\hline Kelly & Female & Widow & Zambian & Junior lecturer & 7 \\
\hline Teshi & Female & Single & Zimbabwean & Junior lecturer & 9 \\
\hline Sue & Female & Married & Zimbabwean & Senior lecturer & 9 \\
\hline Sean & Male & Married & Cameroonian & Senior lecturer & 17 \\
\hline Mark & Male & Married & Kenyan & Associate professor & 5 \\
\hline Paul & Male & Married & Cameroonian & Junior lecturer & 6 \\
\hline Mercy & Female & Married & Zimbabwean & Senior lecturer & 9 \\
\hline Peter & Male & Married & Zimbabwean & Professor & 2 \\
\hline John & Male & Single & Zimbabwean & Junior lecturer & 19 \\
\hline David & Male & Married & Tanzanian & Junior lecturer & 7 \\
\hline Azo & Male & Married & Nigerian & Visiting professor & 2 \\
\hline Bill & Male & Married & Congolese & Junior lecturer & 7 \\
\hline Lily & Female & Married & Ugandan & Junior lecturer & 26 \\
\hline Robin & Female & Single parent & Zimbabwean & Junior lecturer & 11 \\
\hline Ted & Male & Married & Zimbabwean & Associate professor & 16 \\
\hline Eve & Female & Married & Zimbabwean & Junior lecturer & - \\
\hline Angie & Female & Single & Zimbabwean & Junior lecturer & 12 \\
\hline Sam & Female & Married & Nigerian & Senior lecturer & 10 \\
\hline Wayne & Male & Married & Kenyan & Professor & 5 \\
\hline Emily & Female & Single parent & Nigerian & Junior lecturer & 7 \\
\hline
\end{tabular}


themes and using quotes based on consistencies across participant stories. This method allowed for understanding individual sense making around each story (Chinyamurindi, 2016) and understanding ensuing complexities around the lived experiences (Maree \& Beck, 2004).

\section{Strategies to ensure data quality and reporting}

In order to ensure data quality, the researchers adhered to suggestions from the literature (Denzin \& Lincoln, 2005; Sitko, 2013). First, data were collected over a 6-month time frame to avoid research fatigue. Furthermore, a pilot sample was used prior to the start of the main study as a means of testing the waters and dealing with any anticipated challenges. All interviews were transcribed within 24 hours of the interviews being conducted. The researchers collected data until a point where new data did not create new themes. An integration and triangulation of diverse qualitative data sources were applied (e.g. interviews and observations) to check the consistency of findings. In addition, the researchers ensured that the analysis served the purpose of the inquiry. Researcher triangulation amongst the three academics was useful in analysing of data and reducing bias. Finally, as used in previous work adopting narrative analysis (e.g. Chinyamurindi, 2012, 2016), pseudonyms were used to protect participants in the study.

\section{Research results and findings}

Based on the data analysis, four main factors emerged as serving as motivation to expatriate. Table 2 presents a summary of these factors and how they served as a basis for the rationale to expatriate. The second finding is around the experiences of the academics while in South Africa. Table 3 presents some of these challenges and illustrating quotes.

\section{Motivating factors to expatriate}

Table 2 presents the factors contributing as motivation to expatriate. Participants considered factors specific to their own preference and allurement that South Africa, as a country, offers as compared with their home countries. In essence, the factors shown in Table 2 and the illustrating quotes can be considered as either push factors or pull factors.

TABLE 2: Motivating factors to expatriate.

\begin{tabular}{|c|c|}
\hline Motivating factor & Meaning \\
\hline $\begin{array}{l}\text { The need to } \\
\text { further studies }\end{array}$ & $\begin{array}{l}\text { The motivating desire to } \\
\text { access educational } \\
\text { opportunities in South Africa } \\
\text { as a basis for improvement. }\end{array}$ \\
\hline $\begin{array}{l}\text { The worsening } \\
\text { economic } \\
\text { and political } \\
\text { conditions in the } \\
\text { home country }\end{array}$ & $\begin{array}{l}\text { The decision to expatriate as } \\
\text { influenced by home country } \\
\text { factors that relate to the } \\
\text { economy and politics of the } \\
\text { country. The decision to } \\
\text { expatriate was influenced by } \\
\text { the worsening situation } \\
\text { relating to such factors. }\end{array}$ \\
\hline
\end{tabular}

Illustrating quotes

I just saw an opportunity, I saw an advert. I was working at the University of Zimbabwe as a Research Assistant. Then an advert came and they were looking for, it was an NRF scholarship, candidates from Southern Africa. I was also looking for

opportunities to do my Masters. So I just applied and got the funding. (Robin, Female, Zimbabwean)

I worked here in South Africa as a teacher for a year in Pretoria before we moved to Fort Hare when my husband got a job here at Fort Hare and that is when I decided to continue with my studies. (Kelly, Female, Zambian)

Well, when I came to South Africa initially I was coming because I was furthering my studies, which was the primary reason why I came this side. (Mercy Female, Zimbabwean)

To continue with my studies. Because my government sent me here under a scholarship to continue my studies. (Jim, Male, Eritrean)

Well, first of all after my rating, Kenya would not have been my first choice because there are many things such as the pay ratio, and since I have left Kenya, there has been an economic collapse. (Mark, Male, Kenyan)

Well, at that time I had another option at the University of Zimbabwe but by then, the situation was not conducive for learning (economically and politically). (Teshi, Female, Zimbabwean)

After graduating, I couldn't get any form of job to better myself given my background so I was now forced to find a way to raise money. So I did farming, you know farming in my home is done at a subsistence level, I did farming for 2 years raising money, and moved out of the country to South Africa to look for a better life. (Sean, Male, Cameroonian)

When I started working, my country was undergoing, it was during the amnesty time, and those were terrible times economically and socially in Uganda. (Lily, Female, Ugandan)

Because the situation back home will continue like that. The political wars will continue for a long time, so I'm not planning on going back home any time soon. (Jim, Male, Eritrean))

So when things got bad in Zimbabwe (economically and politically) we decided to move to South Africa. (Kelly, Female, Zambian)

$\begin{array}{ll}\begin{array}{l}\text { New life } \\ \text { experience }\end{array} & \text { Search of self-fulfilling jobs } \\ \text { in other countries. }\end{array}$

I'm an ambitious person so I felt that in NGOs there wasn't so much for to develop. I felt that maybe I wasn't moving in the social radar and academic was a good opportunity because you could see yourself moving. (Mark, Male, Kenyan) There were opportunities but I just decided to step out of my comfort zone, and experience life outside my own country. (Robin, Female, Zimbabwean)

You know I will give you a simple example, you have a player who is playing for Manchester United and he is doing very wel and all of a sudden, he decides to go and play for Real Madrid. It doesn't mean that Manchester United is now bankrupt, but he wants new exposures and new challenges. One of the things which I like new exposure and new challenges and coming into academics brings me those. One of the things that I really cherished when I joined the university was carrying out research, the university offered me an opportunity to do research as one of my core activities. (Peter, Male, Zimbabwean)

I was looking for a new challenge as working had become boring and monotonous as I was doing the same thing over and over. There was lot of work that needed to be done and, you know when you are a professor, everyone will be looking up to you to do most work. I didn't want to come to SA but for the sake of looking for a new challenge, I had to move from Kenya as I had worked there for nearly 2 decades. (Wayne, Male, Kenyan)

South African universities' facilities are up to standard and also the work environment to do your research is better, freedom of academic environment is there. (Conrad, Male, Ethiopian)

In Nigeria we do not have much opportunity for research funding, but I'm impressed by the South African government because of the priority they place on research; that is what motivated me to come here, because I have facilities to carry out research. (Azo, Male, Nigerian)

The difference I can say is based on the language, because in DRC we were taught in French; everything is done in French so that is what is making the difference. In South Africa, students are exposed to more facilities than back home. (Bill, Male, Congolese)

Well, it's a free country, and I'm in political science, which is a very sensitive area as far as writing is concerned because there is always these tensions between, in most African countries, the academia and government as far as criticisms are concerned. In South Africa, you have the luxury of expressing yourself by saying whatever you want about the government or any other government without fear of prosecution. (Paul, Male, Cameroonian) 
TABLE 3: Challenges faced by expatriates.

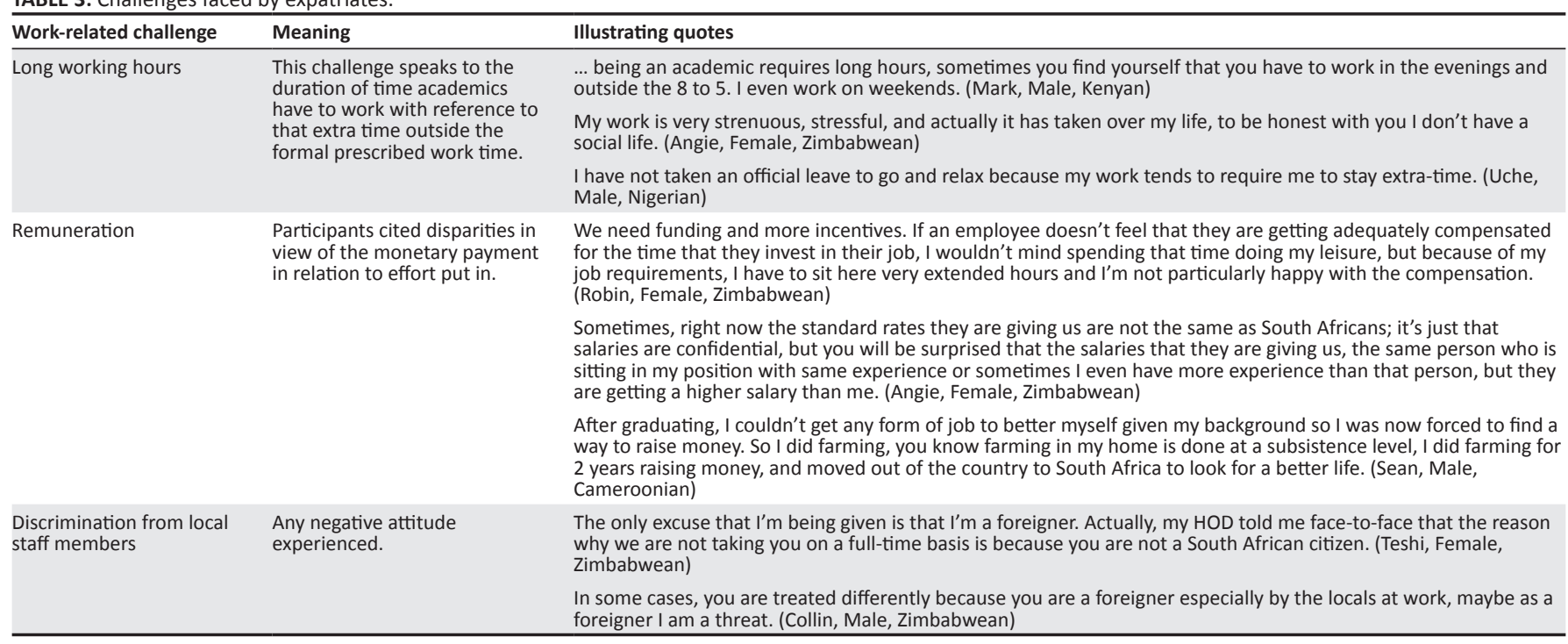

The need for further studies for the academics who participated in this research entailed acquiring postgraduate qualifications and improving their research acumen. South Africa appeared to be a country of choice given the opportunities available through the National Research Foundation (NRF). Thus, to the participants, furthering their academic studies in South Africa was not as an end in itself, but a way out of the challenges faced in their home countries.

Further, the worsening economic and political conditions in their home countries appear to have an influence on the individuals' decision to expatriate (see table for illustrating quotes). Participants viewed South Africa as a country with a favourable economic and political climate, thus allowing for expression without troubles as compared with their home countries. One participant (Jim) from Eritrea expressed the view that even if things get better in his home country, he 'will never go back':

Last week my own father died, I can't even go back to bury my own father. Even if I go, I will never return back. This is due to my visa and also the bad political and economic situation. (Jim, male, married)

In addition to the two identified factors contributing to expatriating, participants also cited the need for a new life experience outside their home country. However, this factor is to be viewed simultaneously with an individual's desire to develop one's career. Because of challenges in the home country, South Africa was perceived to be offering the potential for opportunity. In addition to the illustrating quotes in Table 3 the story offered by Collin can be cited as an example. Collin left a good job in his home country due to challenges (economic and political) to come to South Africa. For Collin, South Africa added the attraction of a 'new experience':

It was about time for a new experience, I hated the predictability of my life and a new start was just the launching pad I needed to move. Having worked in an NGO, academia was to be part of my quest for a new experience. New career path and a new country. (Collin, male, married)
A final factor motivating expatriation was reported to be the perception of good resources and facilities in South Africa. These resources and facilities were varied. Some women participants cited 'good schools for their children' and other participants cited resources such as 'skilled and internationally acclaimed professors'. For example, Conrad, who is a senior lecturer in Soil and Pasture Science, first came to South Africa as a student but upon completion of his studies, he went to work in Swaziland and Namibia before joining the South African academic sector because of the 'facilities and resources' which would help him contribute more:

South African universities' facilities and resources are up to standard and also the work environment to do your research is better, freedom of academic environment is there. (Conrad, male, married)

The study also focused on the experience of being an SiE. Participants described this to be challenging with the source of this emanating from (1) work and (2) non-work-related challenges.

\section{The self-initiated expatriates experience as a challenge}

Table 3 presents a summary of the SiE experiences summated as work and non-work-related challenges.

Non-work-related challenges appear to characterise the $\mathrm{SiE}$ experience. These are the factors outside the formal employment contract. Accommodation issues appeared to pose a great challenge to SiEs. Although the university offered accommodation, it was insufficient for all its staff members, which meant that some participants had to look for their own places to stay. In some cases, participants had to travel long distances to and from towns as far as $120 \mathrm{~km}$ from the university.

For instance, Paul described the commuting between towns as a 'life risk' as he spends a third of his day on the road:

my biggest challenge has been accommodation; I have had to stay very far away from my workplace as an expatriate, driving 
long distances consumed my time and also did not give me a little bit of peace of mind; the time I travelled between my home and my workplace could have been better utilised. (Paul, male, married)

In some cases, the lack of accommodation for $\mathrm{SiE}$ resulted in participants like Conrad sending their families back home:

I couldn't get the right accommodation and as a result, I was forced to send my family back home, and living without them is very difficult. (Conrad, male, married)

Linked to the challenge of accommodation was the challenge of family separation. It was not only the lack of accommodation that resulted in the separation of families as in Conrad, but also the local culture and life outside their home country which some families could not adjust to. The stories of Sean and Kelly appear to reveal this. Both participants are separated from their families. Sean's family 'struggled' to integrate to the local culture and conditions given the difference between his home country (Cameroon) and South Africa:
... my family speaks French, here in South Africa, especially in Alice, I could not find a French speaking school. Further, our cultures are just too different. Career wise, I could adjust, but it was tough and my family struggled. We made a decision to send the family back to Cameroon for their own benefit. The distance is killing us. (Sean, male, married)

Conversely Kelly, after losing her husband, decided to send her family back to Zambia. The thinking around this was motivated around how the experience of being in South Africa reminded the children of their father. Further, Kelly had to work extra hard and at times she could not cope:

I realised because of the long hours of work, I had no time for the children. The children were literally being brought up by the nanny as I was always not there. Further, the death of my husband did not go well with the kids. The best I could do was send the kids back home. It was a good decision, it's so tough to deal with now. (Kelly, female, widow)

A non-work-related challenge was the discrimination SiEs had to endure from members of the community. In all cases, participants narrated this to be an identity issue stemming from the fact that they were foreigners in South Africa. For instance, Lilly described her 'foreignness' as a 'threat to locals' and subsequently affecting her integration in her community. Collin put it succinctly:

\footnotetext{
... everywhere you go, there is this icy stare from the locals. At the supermarket, I am not too light enough. When getting petrol, why I am speaking English and not Xhosa. When searching [for] a school for my child, you get 101 questions. I will always be a foreigner in this country, a badge that comes with challenges. (Collin, male, married)
}

Finally, some challenges emanated from the work-setting of the expatriates. The SiEs also experienced challenges within their formal employment contracts. Long working hours seemed to be the main challenge, and all the participants reiterated that a normal working week was not enough for them to do their work. Because of the flexibility and work load in the academia, participants found themselves working on weekends. Angie, for example, did not have a 'social life' because of the work load. In some instances, participants, such as Uche, were no longer taking leave days because of the work load:

I have not taken an official leave to go and relax because my work tends to require me to stay extra-time. (Uche, male, married)

Despite devoting several hours of their time, the monetary compensation did not reflect their immense efforts. For personal and career development reasons, participants such as Robin had to work for extended hours despite 'a lack of funding and incentives'. Furthermore, the institution had a dual salary policy in the sense that the locals and expatriates were being remunerated differently although equally skilled. Angie concisely expressed the predicament:

Sometimes, right now the standard rates they are giving us are not the same as South Africans', it's just that salaries are confidential, but you will be surprised that the salaries that they are giving us, the same person who is sitting in my position with same experience or sometimes I even have more experience than that person, but they are getting a higher salary than me. (Angie, female, single)

Finally, a work-related challenge SiEs had to endure was discrimination from local staff members. In most cases, participants were treated unfairly, which hindered their career and personal development. Participants' 'foreignness' did not only affect their integration into the community but also in the workplace as Collin felt that his nationality was a 'threat', consequently hampering their career development. In some cases, because of nationality, participants were not being given a chance in their respective departments. Succinctly put by Teshi:

The only excuse that I'm being given is that I'm a foreigner. Actually, my HOD told me face-to-face that the reason why we are not taking you on a full-time basis is because you are not a South African citizen. (Teshi, female, single)

\section{Ethical considerations}

Ethics approval was sought and obtained from the university where the study was conducted. Furthermore, before participation, the participants were asked to sign a written informed consent form that summarised all known potential benefits, confidentiality issues, risks associated with the research and how the data will be used.

\section{Discussion Outline of the findings}

This study investigated the factors and experiences of SiEs in South Africa. Factors that influenced expatriation were multifaceted. The main factors behind expatriation were identified as follows: (1) a need for further studies, (2) worsening political and economic conditions in the home 
country, (3) need for new life experience and (4) perception of good resources and facilities in South Africa. Despite the benefits associated with SiEs, the experience of being an $\mathrm{SiE}$ presents itself as a challenge, with the challenges emanating from work-related and non-work-related challenges. Workrelated challenges are factors within the formal employment contract, while non-work-related ones are outside the formal employment contract.

\section{Relating main findings to literature}

The findings of this study are consistent with the existing literature on factors influencing expatriation and $\mathrm{SiE}$ experiences. Previous studies have shown that people seek expatriation as a way to escape from their current situations (Selmer \& Lauring, 2010; Van den Bergh \& Du Plessis, 2012). Many of the participants originated from countries with poor economic and political conditions. This supports previous studies' findings that economic and political conditions act as a motivational factor to expatriate (Al Ariss \& Syed, 2011; Carr et al., 2005; Thorn, 2009).

Furthermore, current research participants mentioned that because of the need to experience new lives in other countries and develop their careers, they were motivated to expatriate. New life experiences and career development have been noted as some of the major factors that influence expatriation (Andresen et al., 2012; Froese, 2012; Mostert, 2014; Van den Bergh \& Du Plessis, 2012). In addition, through good resources and facilities, participants were able to advance and develop their careers (Andresen et al., 2012). Participants of this research can be viewed as refugees who are architects and mercenaries (Fitzgerald \& Howe-Walsh, 2008; Richardson \& McKenna, 2002). This research revealed that SiEs are not solely driven by the desirability of the job, but rather the poor economic and political conditions in their home countries.

On the contrary, findings of previous studies (Inkson, Arthur, Pringle \& Barry, 1997; Myers, 2013; Richardson \& McKenna, 2002; Van den Bergh \& Du Plessis, 2012) cited that exploration acted as a motivator to expatriate. However, as found in this study, exploration amongst SiEs comes as a secondary factor; perhaps this is because of the sample being from developing countries. Although SiEs' experiences are described as beneficial (Al Ariss \& Ozbilgin, 2010; Scurry, Rodriguez \& Bailouni, 2013; Thorn, 2009), the experience is characterised by several challenges (Richardson \& Zikic, 2007).

A great challenge for the participants was accommodation (Froese, 2012). As in previous studies, lack of housing led to family separation which eventually led to loneliness (Mostert, 2014). Furthermore, the inability of the family members to adapt to the host country's culture and language led to family separation (Van den Bergh \& Du Plessis, 2012). Furthermore, as in previous studies, most participants felt like outsiders because of culture and language differences which made it difficult for them to blend in with the community (Froese, 2012; Richardson \& McKenna, 2002).
The participants also faced work-related challenges. Money is one of the major motivators to expatriate, as illustrated in previous studies (Andresen et al., 2012; Richardson \& Mallon, 2005; Selmer \& Lauring, 2010). Although participants received compensation, it did not reflect their work efforts. Furthermore, lack of support from the institution demoralised the participants (Froese, 2012; Mostert, 2014). Because of discrimination, participants always lived in fear of the unknown (Richardson \& McKenna, 2002; Richardson \& Zikic, 2007).

This study contributes to the understanding of factors that influence expatriation and SiEs' experiences (Alshammari, 2013). The focus was on people who are from developing countries and move between developing countries as it is a neglected sample. This research has responded to calls for understanding SiEs as the decision to expatriate no longer lies with the organisation (Froese, 2012, Selmer \& Lauring, 2011a).

\section{Practical implications}

Many countries are facing talent shortages. Organisations should perceive SiEs as valuable human resources. Attracting and retaining skilled workers is an important issue. The South African government should account for its reliance on skilled SiEs within South Africa and the positive impact SiEs have on the economy. Furthermore, organisations should accept that skilled SiEs play an important role in the development of local employees through development of transferable skills or knowledge-sharing. SiEs are viewed as less expensive labour and equally skilled compared with traditional expatriates. As SiEs are escaping from economic and political hardships, they may be more likely to accept job offers. However, organisations should not exploit this group of employees. Further, SiEs should not be seen as a homogenous group who expatriate for the same reason.

The organisations should assist SiEs to attain houses as it was illustrated as one of the major challenges faced by SiEs. Additionally, organisations should create social networks for the SiEs and their families to adjust quicker to the host country's culture and language. In order for the academics to be productive, organisations need to offer SiEs competitive remuneration to show their appreciation of the work being carried out by expatriates. Institutions need to provide sufficient support to SiEs, for example, in their research work, in order to retain and increase the levels of commitment of the SiEs. Finally, organisations should also educate the university employees and broader community on how to embrace individual differences and not discriminate on the basis of country of origin and any other demographic differences.

\section{Limitations of the study and future research areas}

Some limitations exist within this work. Firstly, the study focused on African SiEs who are based in South Africa, 
and the discoveries of this study may not be applied to other countries and continents. Secondly, only one institution was used for this study, the findings are not generalisable. Thirdly, most of the participants in the study were black Africans, and this can be noted as a further limitation. However, the demographic make-up of the participating university is mainly composed of the black African group especially amongst SiEs. Finally and because of the nature of the qualitative paradigm, though the sample size was deemed to be small, it has assisted as argued by Chinyamurindi (2016) in emerging sense making around the topic under study.

Although enlightening, the findings from this study of selfinitiated academic expatriates may not be generalised to other professions of SiEs. Therefore, future studies should make use of samples of employees from different professions, especially the ones in the business world. Given the scarcity of research on SiEs, there are many other areas to explore. Based on the findings of this study, there is a need to conduct more empirical studies in Africa in order to understand the experiences of SiEs who move between developing countries, and to explore the meaning of being an SiE to them. Furthermore, there is a need to study the human resources departments that employ SiEs to find out how they are meeting the needs of the SiEs. Another avenue to be further studied is the experience of the SiEs who move from developed countries to developing countries. In addition, future studies should look at how self-initiated academic expatriates can have a better work-life balance.

\section{Conclusion}

International and global mobility is increasing, and this is opening various opportunities and avenues for skilled individuals to take up work in different countries. Many people are becoming SiEs; however, research about SiEs is still in its infancy. This study contributes to the understanding of the factors influencing SiEs to relocate into South Africa and their experiences as a result of the relocation. The findings of this study provide a future research basis focusing on SiEs that move between developing countries.

\section{Acknowledgements}

The authors are grateful for funding received from The Govan Mbeki Research and Development Centre (GMRDC) at the University of Fort Hare.

\section{Competing interests}

The authors declare that they have no financial or personal relationships that may have inappropriately influenced them in writing this article.

\section{Authors' contributions}

T.T.H. conducted the research as part of his M.COM in Industrial Psychology. N.M.D. and W.T.C. supervised T.T.H. in his studies and jointly assisted in writing this article.

\section{References}

Abele, A.E, Spurk, D., \& Volmer, J. (2012). Career stagnation: Underlying dilemmas and solutions in contemporary work environments. In N.P. Reilly, J.M. Sirgy, \& C.A. Gorman (Eds.), Work and quality of life (pp. 107-132). Dordrecht: Springer.

Ainuddin, R.A., \& Lily, J. (2012). Expatriate adjustment and perceptions of liability of foreignness among self-initiated expatriates and assigned expatriates in Malaysia. Sabah, Malaysia: School of Business and Economics, University of Malaysia, pp. $1-7$.

Al Ariss, A., Cascio, W.F., \& Paauwe, J. (2013). Talent management: Current theories and future research directions. Journal of World Business, 49(2), 173-179. https:// doi.org/10.1016/j.jwb.2013.11.001

Al Ariss, A., \& Özbilgin, M. (2010). Understanding self-initiated expatriates: Career experiences of Lebanese self-initiated expatriates in France. Thunderbird International Business Review, 52(4), 275-285. https://doi.org/10.1002/ tie. 20355

Al Ariss, A., \& Syed, J. (2011). Capital mobilization of skilled migrants: A relational perspective. British Journal of Management, 22(2), 286-304. https://doi. org/10.1111/j.1467-8551.2010.00734.x

Alshammari, H. (2013). The adjustment of self-initiated expatriate academics in higher education institutions in Saudi Arabia. College of Business: School of Management, RMIT University. Retrieved September 19, 2014, from https://researchbank.rmit. RMIT University. Retrieved
edu.au/view/rmit:160615

Altbach, P.G. (2004). Globalisation and the university: Myths and realities in an unequal world. Tertiary Education and Management, 10(1), 3-25.

Andresen, M., Al Ariss, A., \& Walther, M. (2012). Self-initiated expatriation: Individual, organisational and national perspective. New York: Routledge.

Baruch, Y., Dickmann, M., Altman, Y., \& Bournois, F. (2013). Exploring internationa work: Types and dimensions of global careers. The International Journal of Human Resource Management, 24(12), 2369-2393.

Beaverstock, J.V. (2005). Transnational elites in the city: British highly-skilled intercompany transferees in New York City's financial district. Journal of Ethnic and Migration Studies, 31(2), 245-258. https://doi.org/10.1080/136918304200033 9918

Buthelezi, M. (2009). An investigation of the experiences and meaning of xenophobia at the University of Zululand by international students. Unpublished master's thesis, University of Zululand, KwaZulu-Natal, South Africa.

Cao, L., Hirschi, A., \& Deller, J. (2013). The positive effects of a protean career attitude for self-initiated expatriates: Cultural adjustment as a mediator. Career Development International, 18(1), 56-77. https://doi.org/10.1108/1362043131 1305953

Carr, S.C., Inkson, K., \& Thorn, K. (2005). From global careers to talent flow: Reinterpreting 'brain drain'. Journal of World Business, 40(4), 386-398. https:// doi.org/10.1016/j.jwb.2005.08.006

Chen, Y. (2012). Three-stage process model of self-initiated expatriate career transitions: A self-determination theory perspective. Milwaukee: University of Wisconsin.

Chinyamurindi, W.T. (2012). An investigation of career change using a narrative and story-telling inquiry. South African Journal of Human Resource Management, 10(2), 1-11. https://doi.org/10.4102/sajhrm.v10i2.447

Chinyamurindi, W.T. (2016). A narrative investigation into the meaning and experience of career success: Perspectives from women participants. South African Journal of Human Resource Management, 14(1), 1-11. https://doi.org/10.4102/sajhrm. v14i1.659

Creswell, J.W. (2009). Research design, qualitative and quantitative and mixed methods approaches. (4th edn.). London: Sage.

Denzin, N.K., \& Lincoln, Y.S. (Ed.). (2005). Handbook of qualitative research. (3rd edn.). Thousand Oaks, CA: Sage. In Nicholson, N. (2000). Motivation-selectionconnection: An evolutionary model of career development. In M. Peiperl, M. Arthur, R. Goffee, \& T. Morris (Eds.), Career frontiers: New concepts of working life Arthur, R. Goffee, \& T. Morris (Eds.), Career fro
(pp. 54-75). Oxford: Oxford University Press.

Doherty, N. (2013). Understanding the self-initiated expatriate: A review and directions for future research. International Journal of Management Reviews, 15(4) 447-469. https://doi.org/10.1111/ijmr.12005

Doherty, N., Richardson, J., \& Thorn, K. (2013). Self-initiated expatriation: Career experiences, processes and outcomes. Career Development International, 18(1), 6-11. https://doi.org/10.1108/13620431311305917

Fitzgerald, C., \& Howe-Walsh, L. (2008). Self-initiated expatriates: An interpretative phenomenological analysis of professional female expatriates. International Journal of Business Management, 3(10), 156-175.

Froese, F.J. (2012). Motivation and adjustment of self-initiated expatriates: The case of expatriate academics in South Korea. The International Journal of Human Resource Management, 23, 1095-1112. https://doi.org/10.1080/09585192.2011. 561220

Guba, E.G., \& Lincoln, Y.S. (1994). Competing paradigms in qualitative research. In N.K. Denzin \& Y.S. Lincoln (Eds.), Handbook of qualitative research (pp.105-117). Thousand Oaks, CA: Sage.

Hall, D.T. (2002). Protean careers in and out of organizations. Thousand Oaks, CA: Sage.

Haslberger, A., \& Vaiman, V. (2013). Self-initiated expatriates: A neglected source of the global talent flow. In V. Vaiman \& A. Haslberger (Eds.), Talent management of the global talent flow. In V. Vaiman \& A. Haslberger (Eds.), Talent management of Hampshire: Palgrave Macmillan. 
Howe-Walsh, L., \& Schyns, B. (2010). Self-initiated expatriation: Implications for HRM International Journal of Human Resources Management, 21, 260-273. https:// doi.org/10.1080/09585190903509571

Inkson, K., Arthur, M.B., Pringle, J., \& Barry, S. (1997). Expatriate assignment versus overseas experience: Contrasting models of international human resource management. Journal of World Business, 32(4), 351-368. https://doi.org/10.1016/ S1090-9516(97)90017-1

Inkson, K., Gunz, H., Ganesh, S., \& Roper, J. (2012). Boundaryless careers: Bringing back boundaries. Organization Studies, 33(3), 323-340. https://doi.org/10.1177/ 0170840611435600

Inkson, K., \& Richardson, J. (2010). Self-initiated expatriation and career development Diversity across cultures and genders (pp.6-10). Montreal, Canada: Academy of Management.

International Labour Organisation. (2010). International labour migration: A rights based approach (p. 18). Geneva, Switzerland: International Labour Office.

Jokinen, T., Brewster, C., \& Suutari, V. (2008). Career capital during international work experiences: Contrasting self-initiated expatriate experiences and assigned
expatriation. International Journal of Human Resource Management, 19, 979-998. https://doi.org/10.1080/09585190802051279

Maree, J. G., \& Beck, G. (2004). Using various approaches in career counselling for traditionally disadvantaged (and other) learners: Some limitations of a new traditionally disadvantaged (and other) learners: So
frontier. South African Journal of Education, 24, 80-87.

Maharaj, A. (2011). The impact of globalisation on South African higher education institutions: Patterns of academic inflow into the South African higher education system. Delhi Business Review, 12(1), 1-14.

Merriam, S.B. (2002). Qualitative research in practice: Examples for discussion and analysis. (1st edn.). San Francisco, CA: Jossey-Bass.

McCormack, C. (2000). From interview transcript to interpretative story: Part 1. Viewing the transcript through multiple lenses. Field Methods, 12(4), 282-297.

Mostert, E. (2014). Exploring push and pull factors experienced by South African selfinitiated 'expatriates. Unpublished master's dissertation. Human Resources Department, University of Pretoria, Pretoria.

Myers, B. (2013). Volunteer self-initiated expatriation: Alternative career development pathways for older women? In The 2013 Conference of Equality, Diversity and EDI $01-03$ July 2013 (pp. 1-21). Athens, Greece: Athens University of Economics and Business.

Nachmias, F.C., \& Nachmias, D. (1996). Research methods in the social sciences. (5th edn.). New York: Worth.

Reuben, S., \& Bobat, S. (2014). Constructing racial hierarchies of skill - Experiencing affirmative action in a South African organisation: A qualitative review. South African Journal of Industrial Psychology, 40(1), 1-12.

Richardson, J. (2006). Self-directed expatriation: Family matters. Personnel Review, 35 469-486. https://doi.org/10.1108/00483480610670616

Richardson, J. (2009). Geographic flexibility in academia: A cautionary note. British Journal of Management, 20(1), 160-170. https://doi.org/10.1111/j.1467-8551. 2008.00641.x

Richardson, J., \& Mallon, M. (2005). Career interrupted: The case of the self-directed expatriates. Journal of World Business, 40, 409-420. https://doi.org/10.1016/j. jwb.2005.08.008

Richardson, J., \& McKenna, S. (2002). Leaving and experiencing: Why academics expatriate and how they experience expatriation. Career Development International, 7(2), 57-68. https://doi.org/10.1108/13620430210421614

Richardson, J., \& McKenna, S. (2003). International experience and academic careers: What do academics have to say? Personnel Review, 32(6), 774-795. https://doi. org/10.1108/00483480310498710

Richardson, J., \& Zikic, J. (2007). The darker side of an international academic career Career Development, 12(2), 164-186. https://doi.org/10.1108/13620430710 733640

Riessman, C.K. (2008). Narrative methods for the human sciences. London: Sage.
Rodriguez, J.K., \& Scurry, T. (2014). Career capital development of self-initiated expatriates in Qatar: Cosmopolitan globetrotters, experts and outsiders. The International Journal of Human Resource Management, 25(2), 190-211.

Rubin, H.J., \& Rubin, I. (2005). Qualitative interviewing: The art of hearing data. Thousand Oaks, CA: Sage.

Ryan, J., Silvanto, S., \& Ozkaya, H.E. (2015). A contextual, theoretical and empirical analysis of the uses of university degrees as symbolic capital in self-initiated expatriation. European Journal of International Management, 9(5), 614-634.

Saleh, I. (2015). Is it really xenophobia in South Africa or an intentional act of prejudice? Global Media Journal-African Edition, 9(2), 298-313.

Scurry, T., Rodriguez, J.K., \& Bailouni, S. (2013). Narratives of identity of self-initiated expatriates in Qatar. Career Development International, 18(1), 12-33. https://doi. org/10.1108/13620431311305926

Sebola, M.P. (2015). Scarce skills expatriates in South African universities: Rhetoric and realities of the 'Messianic' academics. The Journal for Transdisciplinary Research in Southern Africa, 11(4), 180-192. https://doi.org/10.4102/td.v11i4.53

Selmer, J., \& Lauring, J. (2010). Self-initiated academic expatriates: Inherent demographics and reasons to expatriate. European Management Review, 7(3), 169-179. https://doi.org/10.1057/emr.2010.15

Selmer, J., \& Lauring, J. (2011a). Acquired demographics and reasons to relocate among self-initiated expatriates. International Journal of Human Resource Management, 22, 2055-2070. https://doi.org/10.1080/09585192.2011.580176

Selmer, J., \& Lauring, J. (2011b). Expatriate academics: Job factors and work outcomes. International Journal of Manpower, 32(2), 194-210. https://doi.org/10.1108/0143 7721111130206

Selmer, J., \& Lauring, J. (2012). Reasons to expatriate and work outcomes of selfinitiated expatriates. Personnel Review, 41 665-684. https://doi org/10.1108/00483481211249166

Singh, R.J. (2013). Examining xenophobic practices amongst university students: A case study from Limpopo Province. Alternation Special Edition, $7(1), 88-108$

Silvanto, S., \& Ryan, J. (2014). Relocation branding: A strategic framework for attracting talent from abroad. Journal of Global Mobility, 2(1), 102-120. https://doi. org/10.1108/JGM-07-2013-0046

Sitko, N.J. (2013). Qualitative methods: Data analysis and validation. Lusaka, Zambia: Indaba Agricultural Policy Research Institute.

Sorensen, T. (2012). The lived experience of xenophobia within a South African university. Unpublished master's thesis. Port Elizabeth, South Africa: Nelson Mandela Metropolitan University

Suutari, V., \& Brewster, C. (2000). Making their own way: International experience through self-initiated foreign assignments. Journal of World Business, 35, 417 436. https://doi.org/10.1016/S1090-9516(00)00046-8

Tams, S., \& Arthur, M.B. (2010). New directions for boundaryless careers: Agency and interdependence in a changing world. Journal of Organisational Behaviour, 31 629-646. https://doi.org/10.1002/job.712

Tharenou, P., \& Caulfield, N. (2010). Will I stay or will I go? Explaining repatriation by self-initiated expatriates. Academy of Management Journal, 53(5), 1009-1028. https://doi.org/10.5465/AMJ.2010.54533183

Thorn, K. (2009). The relative importance of motives for international self-initiated mobility. Career Development International, 14(5) 441-464. https://doi. org/10.1108/13620430910989843

Thornhill, H., Clare, L., \& May, R. (2004). Escape, enlightenment and endurance: Narratives of recovery from psychosis. Anthropology and Medicine, 11, 181-199. https://doi.org/10.1080/13648470410001678677

Van den Bergh, R., \& Du Plessis (2012). Highly skilled migrant women: A caree development framework. Journal of Management Development, 31(2) 142-158. https://doi.org/10.1108/02621711211199485

Volpe, E.H., \& Murphy, W.M. (2011). Married professional women's career exit Integrating identity and social networks. Gender in Management: An internationa Journal, 26(1), 57-83. https://doi.org/10.1108/17542411111109318 